\title{
Contributors
}

ERIK ECKHOLM is a reporter for the New York Times and was the paper's Beijing bureau chief from 1998 to 2003.

Joan KaUfman is director of the AIDS Public Policy Training Program at Harvard's Kennedy School of Government and lecturer in social medicine, Harvard Medical School. She is also senior scientist, Schneider Institute for Health Policy, Brandeis University.

ARTHUR KLEINMAN is Sidney Rabb Professor of Anthropology (Faculty of Arts and Sciences) and professor of medical anthropology and psychiatry, Harvard Medical School, Harvard University.

DOMINIC LEE is professor, Department of Psychiatry, Chinese University of Hong Kong.

SING LEE is professor, Department of Psychiatry, Chinese University of Hong Kong.

MEGAN MURRAY is assistant professor of epidemiology, Harvard School of Public Health, and an infectious disease physician at Massachusetts General Hospital, Boston.

THOMAS G. RAWSKI is professor of economics and history and University Center for International Studies Research Professor, University of Pittsburgh. 
TONY SAICH is Daewoo Professor of International Affairs, Kennedy School of Government, Harvard University.

A L AN SCHNUR served as team leader, Communicable Disease Control, World Health Organization, Beijing Office.

JAMES L. WATS ON is Fairbank Professor of Chinese Society and professor of Anthropology, Harvard University.

Y UN KWOK WING is professor of psychiatry at the Chinese University of Hong Kong.

HONG ZHANG is assistant professor of anthropology, Colby College. 


\section{SARS in China}


This page intentionally left blank 